\title{
Book Review: Bakich,O. M. (2015). Valerii Pereleshin: Life of a Silkworm Toronto: University of Toronto Press
}

\author{
Kyoko I. Davis \\ University of Toronto, Canada
}

Received: 09-04-2016

Accepted: $12-05-2016$

Published: 01-07-2016

doi:10.7575/aiac.ijclts.v.4n.3p.1

URL: http://dx.doi.org/10.7575/aiac.ijclts.v.4n.3p.1

This is the first and most concise biography of a Russian émigré gay poet, Valerii Pereleshin (1913-1992). The biographer, Olga Bakich, takes on the self-described role of an "accompanist" (xiv) to this prolific, yet understudied poet by painstakingly illuminating the joys and sorrows of his spiritual journey over eight decades. This work causes the reader to reconsider how a biography could be written. The key historical events surrounding his personal life are mentioned but not discussed in the context of historiographical theory. To do so would only distract the reader from the humble existence of Pereleshin as a biographical figure. His unique talent, personality, and literary footprint span vast distances from China's northeast to Brazil. This rather atypical biography consists primarily of the artist's aesthetically subjective testimony- his own poetry.

As a former resident and survivor of war-time Harbin, Bakich herself is well aware of the backdrop of turbulent historical events in the $20^{\text {th }}$ century Far East: Imperial Russia's eastward expansion, the forced and voluntary settlement of migrants from Eastern Europe, the Korean peninsula and Japanese archipelago, Qing China's semi-colonization and its subsequent collapse, the encroachment of Western and Japanese imperialism, the establishment of Japan's puppet state of Manchukuo, World War II and the USSR's advance into the region followed by civil war and the establishment of the People's Republic of China. The poet is a witness, survivor, and victim of these events.

Bakich lets Pereleshin speak through letters, poems and photographs, a testimony of White Russians fleeing from the Eurasian Continent. Part One of Life of a Silkworm covers the period 1920 - 1952 in China, following Pereleshin's intellectual development from childhood to young adulthood. Each of the six chapters in this part is divided into multiple subtopics, covering periods of four to five years: the noble roots of the Salatko-Petrishche family, its relocation to Siberia amidst the chaos of revolution and horrors of civil war, education under the tsarist Russian system in Harbin, and most importantly his growing love for poetry and philosophy.The personal events of Pereleshin's early years document the still understudied but rich history of Russian Orthodox Ecclesiastical Mission in the Far East. Pereleshin, being sensitive and deeply religious, enrolled in the Mission's Theological Faculty in 1937, was ordained a Monk Herman (in honour of St. Herman of Kazan' and Sviiaga) in 1938, and a Priest-Monk Herman in 1941.Harbin émigré literary circle "Churaevka" and the lively interaction among its intellectuals also add new cultural dimensions to the study of Russian émigré society in Asia.

Pereleshin began publishing his books of poetry in 1937.The poet, however, was rather a dissonance in his own conservative community. For example, as a monk, his participation in public poetic activities was limited. Moreover, he was inclined toward Catholicism and admired St. Francis of Assisi and St. Thérèse of Lisieux- a liberal expression of his spiritual interest. He began to travel and preach in Chinese cities with foreign concessions such as Beijing, Shanghai, and Tianjin with a determination to live his life to the fullest by serving God. But Pereleshin had difficulty finding inner peace with his vow of celibacy. While his poetry is infused with divine inspiration, passion and kindness, he was often tormented by the social stigma of his sexuality.

In addition, the volatile political situation in the Far East made Pereleshin mistaken at times for a Japanese spy, a Fascist spy, a Soviet spy, and a Communist. Adversity, however, ignited his poetic creativity, especially after his departure to a third home, Brazil.

Part Two consists of seven chapters covering 39 years of Pereleshin's life in Brazil during the period 1953-1992. The main focus shifts towards his growth as a poet. As a polyglot, he engaged in translations of poetry to and from Russian, Chinese and Portuguese languages. He also wrote some pieces in an avant-garde style, the so-called futurism, as well as preserving his lyrical poetic style. There were some bright moments: émigré scholars and critics in the US, such as Alexis Rannitand Simon Karlinsky recognized Pereleshin as an authentic Russian poet, and offered praise and support. It is an important gesture by Bakich to highlight this aspect of Pereleshin's life. Otherwise, his portrayal as a "tasteless" émigré poet from the east who lacked "Parisian culture" (171), according to one US literary professor, G. Struve, might be accorded more weight than it should. Pereleshin's animosity toward I. Brodsky is also interesting from the perspective of literary history. Whether the result of his jealousy toward this Nobel Prize winner or his anti-Semitic sentiment is unclear; yet in any case, a careful reading of the text reveals that the core issue originated in the poetic language itself, not ethno-religious identity. Even the last country he could have called home offered no respite. Pereleshin faced many financial difficulties and the pain of unrequited love. In the end,he had three homelands, and experienced three exiles. Yet, before his departure for Brazil, he had already sensed that for him, Kitai (China in 
Russian) should be his place to die, because of his fascination with the vivacious and affectionate people who "understood [him] and reciprocated [his] love." (139)

The title of this work is drawn from Pereleshin's own words: "A tender, sticky web, /a fine material, /is produced by a silkworm/ twisting like an invisible snake/from its own self/ (There is nothing else).” (Silkworm, 29.12.1967, xiii) Pereleshin spun more than two thousand poems in his life. Bakich has re-entered his world and has woven a veritable tapestry of his life and art, using the poet's creative work as the warp, and personal events as the weft. The author's effort to present this complex poet in an approachable way using short chronological intervals may, to a certain extent, sacrifice the attractive depth of thematic components expressed in his poetry, namely, Russian émigré identity, religion, philosophy, homosexuality, and poetic inspiration. These topics would be worth pursuing more intensively in Pereleshin's anthology in the near future. For the present, it is the author's willingness to embrace the poet's extremes that is most impressive here. Bakich causes the reader to consider a life lived at the margins of ethnicity, citizenship, spirituality and sexuality - all prominent themes today as we seek to build an inclusive society. For Pereleshin, who was not a social activist, poetry was his only means of self-advocacy. Thankfully, Bakich's work introduces it to us: gentle, lonely, yet so brilliantly strong. 